\title{
Identification of Amino Acids Involved in the Sensory Function of the PrrB Histidine Kinase by Site-directed Mutagenesis
}

\author{
Yong-Jin Kim, In-Jeong $\mathrm{Ko}^{1}$ and Jeong-II Oh* \\ Department of Microbiology, Pusan National University, 609-735 Busan, Korea, \\ ${ }^{1}$ Korea Science Academy, 614-822 Busan, Korea
}

Received February 28, 2006 / Accepted March 28, 2006

\begin{abstract}
The PrrBA two-component system is one of the major regulatory systems that control expression of photosynthesis genes in response to changes in oxygen tension in the anoxygenic photosynthetic bacterium, Rhodobacter sphaeroides. The system consists of the PrrB histidine kinase and the PrrA response regulator. The N-terminal transmembrane domain of PrrB serves as a signal-sensing domain and comprises six transmembrane helices forming three periplasmic loops and two cytoplasmic loops. The $3^{\text {rd }}$ and $4^{\text {th }}$ transmembrane helices and the $2^{\text {nd }}$ periplasmic loop were suggested to play a crucial role in redox-sensory function. In this study we demonstrated that mutations of Asp-90, Gln-93, Leu-94, Leu-98, and Asn-106 in the $2^{\text {nd }}$ periplasmic loop and its neighboring region led to severe defects in PrrB sensory function, indicating that these amino acids might be related to the redox-sensing function of PrrB. The mutant forms (D90E, D90N, and D90A) of PrrB were heterologously overexpressed in Escherichia coli, purified by means of affinity chromatography and their autokinase activities were comparatively assessed. The $\mathrm{D} 90 \mathrm{~N}$ form of $\operatorname{PrB}$ was shown to possess higher autokinase activity than the wild-type form of PrrB, whereas the D90E form of PrrB displayed lower autokinase activity than the wild-type form of PrrB. The D90A mutation led to the loss of PrrB autokinase activity.
\end{abstract}

Key words - Histidine kinase, photosynthesis, redox sensing, site-directed mutagenesis, two-component system

\section{Introduction}

The photosynthetic bacterium Rhodobacter sphaeroides can perform photosynthesis (PS) only when oxygen tensions fall below $\sim 3 \%$ because the intracytoplasmic membrane (ICM) housing the photosynthetic apparatus is synthesized under these conditions[11,19]. The photosynthetic apparatus is composed of the spectral complexes (reaction center and light harvesting complexes I and II), cytochrome $\mathrm{bc}_{1}$ complex, and cytochrome $c_{2}$, which constitute the cyclic, photosynthetic electron transport system[11,19]. The anaerobic induction of PS genes encoding the apoproteins of the spectral complexes and enzymes catalyzing photopigment (bacteriochlorophyll and carotenoid) biosynthesis, is mediated by at least three major regulatory sytems, the PrrBA two-component system, the AppA-PpsR antirepressor-repressor system, and $\operatorname{FnrL}[4-8,26]$.

The PrrBA two-component consists of the PrrB histidine kinase and the PrrA response regulator[4-6]. The PrrB histidine kinase is a bifunctional enzyme that possesses both

\section{*Corresponding author}

Tel : +82-51-510-2593, Fax : +82-51-514-1778

E-mail : joh@pusan.ac.kr kinase and phosphatase activities[2,21]. PrrB is composed of the conserved C-terminal kinase/phosphatase domain and the N-terminal transmembrane domain with six transmembrane helices forming three periplasmic and two cytoplasmic loops[22]. Under anaerobic or $\mathrm{O}_{2}$-limiting conditions the equilibrium of $\operatorname{Pr} B$ kinase/phosphatase activities is in the kinase-dominant mode, the default state of the PrrB activity, resulting in the phosphorylation of PrrA [20]. The phosphorylated PrrA acts as an active transcriptional activator that activates the transcription of most PS genes under anaerobic conditions[9]. On the other hand, the PrrB kinase/phosphatase activities are shifted toward the phosphatase mode under high $\mathrm{O}_{2}$ conditions, which turns off PS gene expression.

The $c b b_{3}$ cytochrome $c$ oxidase, one of the terminal oxidases in the respiratory electron transport chain of $R$. sphaeroides, has been proposed to serve as a redox sensor that controls the equilibrium of the PrrB kinase/phosphatase activities in response to changes in $\mathrm{O}_{2}$ availability $[13,14,18,25]$. The $c b b_{3}$ oxidase generates a signal, which shifts the relative equilibrium of PrrB activity from the kinase mode to phosphatase mode under aerobic conditions. Under $\mathrm{O}_{2}$-limiting or anaerobic conditions, the 
signal emanating from the $c b b_{3}$ oxidase is weakened and the equilibrium of the PrrB activity is thereby in the default state, i.e., the kinase-dominant mode, leading to the induction of PS genes[20]. Using the purified $c b b_{3}$ oxidase, PrrB, and PrrA, it was clearly demonstrated in vitro that the $c b b_{3}$ oxidase inhibits the PrrB activity phosphorylating the PrrA response regulator by increasing the PrrB phosphatase activity without alteration of the PrrB kinase activity[21].

It was proposed by $\mathrm{Oh}$ et al.[20] that the central portion of the PrrB transmembrane domain including the second periplasmic loop plays an important role in the sensory function of PrrB. Recently the central portion of the PrrB transmembrane domain was suggested to serve as the ubiquinone binding site[24].

In this study we performed site-directed mutagenesis to identify the amino acid residues within the second periplasmic loop and its neighboring region of the PrrB transmembrane domain that are important for the sensory function of PrrB. We demonstrated that mutations of Asp-90, Gln-93, Leu-94, Leu-98, and Asn106 led to severe aberration of the sensory function of PrrB.

\section{Materials and Methods}

Growth conditions of bacterial strains. R. sphaeroides and Escherichia coli strains were grown as described previously[16].

DNA manipulations and conjugation techniques. Standard protocols[23] or manufacturer's instructions were followed for recombinant DNA manipulations. Mobilization of plasmids from $E$. coli strains into $R$. sphaeroides strains was performed as described elsewhere[3].

Site directed mutagenesis. To perform point mutations of D90E, D90N, D90A, Q93E, Q93N, Q93A, L94C, L97C, L98C, F99C, L100C, T101C, L104C, N106D, N106Q, N106A, and P107A in PrrB, the plasmid pPRRB5[20], which contains a 1.6-kb KpnI-Pst fragment carrying the $\operatorname{prr} B$ gene with six consecutive histidine codons at its 3 -terminus, was used as a template plasmid for site-directed mutagenesis. Mutagenesis was carried out using the Quick Change Site-Directed Mutagenesis Kit (Stratagene, CA). Synthetic oligonucleotides 33-34 bases long containing an alanine (GCG), cysteine (TGC), glutamate (GAG), asparagines (AAC), glutamine (CAG) or aspartate (GAC) codon in place of the target codon in the middle of their se- quences were used to mutagenize the target codons. Following the verification of mutations by DNA sequencing, a 1.6-kb KpnI-PstI fragment containing the mutated sequence was cloned into the broad host range vector pRK415[10]. The resulting plasmids are introduced into $R$. sphaeroides PrrB1[5], a strain in which the prrB gene has been disrupted by gene replacement.

Purification of wild-type form and mutant forms of PrrB. To overexpress prrB heterologously in E. coli, the plasmid pT7HIS9A[21] was used. The plasmid pT7D90E, pT7D90N, and pT7D90A were constructed to express the mutant forms (D90E, D90N, D90A) of PrrB by site-directed mutagenesis using the plasmid pT7HIS9A.

The wild-type and mutant forms of PrrB were purified as following: the $E$. coli Bl21(DE3) strain carrying pT7HIS9A or its derivatives was grown in Luria-Bertani (LB) medium supplemented with $100 \mathrm{mg} / \mathrm{ml}$ of ampicillin aerobically at $37^{\circ} \mathrm{C}$ to an absorbance of 0.4 to 0.5 at 595 $\mathrm{nm}$. The prrB gene was induced by addition of IPTG to a final concentration of $0.5 \mathrm{mM}$ and cells were further grown for $4 \mathrm{~h}$ at $30^{\circ} \mathrm{C}$. After harvesting of a $4 \mathrm{l}$ culture, cells were washed with buffer A (20 mM Tris- $\mathrm{HCl}[\mathrm{pH} 8.0]$ containing $20 \mathrm{mM} \beta$-mercaptoethanol). Cells were resuspended in $30 \mathrm{ml}$ of buffer $\mathrm{A}$ and disrupted by two passages through a French pressure cell. Following DNase treatment (150 units of DNase [Promega, Madison, WI]) in the presence of $10 \mathrm{mM} \mathrm{MgCl} 2$ for $30 \mathrm{~min}$ at room temperature, cell-free crude extracts were obtained by centrifugation two times at $20,000 \times \mathrm{g}$ for $20 \mathrm{~min}$. Membrane fractions were isolated by ultracentrifugation of crude extracts at $150,000 \times \mathrm{g}$ for $90 \mathrm{~min}$ at $4 \mathrm{C}$. After the membrane fraction (pellet) was washed twice with buffer $A$, the membranes were solubilized in $30 \mathrm{ml}$ of buffer B (buffer A containing 20\% (w/v) glycerol) containing $1 \%(\mathrm{w} / \mathrm{v}) \quad n$-dodecyl $\beta$-D-maltoside (DM) for $2 \mathrm{~h}$ at $4^{\circ} \mathrm{C}$, and then centrifuged at $150,000 \times \mathrm{g}$ for $1 \mathrm{~h}$ at $4^{\circ} \mathrm{C}$. The supernatant was taken as solubilized membrane proteins and used for affinity chromatography. After addition of imidazole to a final concentration of 5 $\mathrm{mM}, 1.5 \mathrm{ml}$ of $50 \%(\mathrm{v} / \mathrm{v})$ nickel-nitrilotriacetic acid HIS-bind slurry (Novagen, Madison, WI) was added to the solubilized membrane proteins and mixed gently by shaking for $15 \mathrm{~h}$ at $4 \mathrm{C}$. The protein-resin mixture was loaded into a column, and the column was washed with 20 volumes of buffer C (buffer B containing $0.05 \%(w / v) D M)$ containing $5 \mathrm{mM}$ imidazole followed by 50 volumes of buffer $\mathrm{C}$ containing $20 \mathrm{mM}$ imidazole. The Hisq-tagged 
PrrB protein was eluted with buffer $C$ containing $200 \mathrm{mM}$ imidazole. The fractions containing the PrrB protein were collected and dialyzed against 11 of buffer $C$ for $5 \mathrm{~h}$ at $4^{\circ} \mathrm{C}$. The desalted PrrB was concentrated by means of ultrafiltration (membrane YM30, Millipore Co, Bedford, MA).

RNA isolation and analysis. Total RNA was isolated from R. sphaeroides strains as described by Oelmuller et al. [15]. Northern hybridization experiments were performed using AlkPhos DIRECT System (American Pharmacia Biotech, Piscataway, NJ) as instructed by the manufacturer.

Quantitative analysis of spectral complexes. The B800-850 and B875 complexes levels were determined spectrophotometrically as described previously[17].

Protein determination and autophosphorylation assay of PrrB. Protein concentration was determined by the bicinchoninic acid protein assay (Pierce, Rockford, IL) using bovine serum albumin as the standard protein.

Autophosphorylation assay was performed at room temperature in assay buffer containing the appropriate amount of PrrB, $20 \mathrm{mM}$ Tris- $\mathrm{HCl}(\mathrm{pH} 8.0), 50 \mathrm{mM} \mathrm{KCl}, 5 \mathrm{mM}$ $\mathrm{MgCl}_{2}, 10-15 \%(\mathrm{w} / \mathrm{v})$ glycerol, $10 \mathrm{mM} \beta$-mercaptoethanol, and $0.025 \%(\mathrm{w} / \mathrm{v}) \mathrm{DM}$. The reaction was initiated by the addition of a mixture of $\left[\mathrm{Y}^{32} \mathrm{P}\right] \mathrm{ATP}$ and unlabeled ATP to final concentrations of $100 \mathrm{mM}(1000 \mathrm{Ci} / \mathrm{mole})$ and incubated for $3 \mathrm{~min}$. The reactions $(10 \mathrm{ml})$ were stopped by the addition of $3 \mathrm{ml}$ of $4 x$ loading buffer $(40 \mathrm{mM}$ Tris- $\mathrm{HCl}$ [pH 6.8], 4\% SDS, $16 \%(\mathrm{w} / \mathrm{v})$ glycerol, $16 \mathrm{mM} \mathrm{DTT}, 1 \% \beta$ -mercaptoethanol, $0.1 \%(\mathrm{w} / \mathrm{v})$ bromophenol blue, and 100 mM EDTA). Samples were denatured for $40 \mathrm{~min}$ at room temperature in sample buffer and ${ }^{32} \mathrm{P}$-labeled $\operatorname{PrrB}$ was resolved by SDS-PAGE using $12.5 \%(\mathrm{w} / \mathrm{v})$ polyacrylamide gels. Gels were dried at $80^{\circ} \mathrm{C}$ under vacuum and the labeled proteins were visualized by autoradiography.

\section{Results and Discussion}

The second periplasmic loop of the PrrB transmembrane domain is well conserved in all PrrB homologues

Using a set of PrrB insertion mutants with lesions in the transmembrane domain, it was suggested that the central portion of the PrrB transmembrane domain is important for the sensory function of $\operatorname{Pr} B[20]$. In agreement with this suggestion, the central region encompassing transmembrane helix 3 , periplasmic loop 2, and transmembrane helix 4 is well conserved at the level of primary structure, when the corresponding region of the PrrB homologues from several photosynthetic bacteria are multiply aligned (Fig. 1). A conspicuous characteristics found within this conserved region is the presence of conserved leucine residues at positions 88,94,97, 98, 100, 104, 110, and 113 (numbering is based on PrrB sequence). In addition, the charged amino acids, Asp-90, Gln-93, and Asn-104, in this region are also conserved in all $\operatorname{PrB}$ homologues. The leucine-rich repeat is found in a variety of proteins and in many cases is involved in protein-protein interactions, which raises the possibility that PrrB receives the signal from the $c b b_{3}$ cytochrome $c$ oxidase by means of protein-protein interaction[12].

Identification of amino acid residues within the PrrB transmembrane domain that are important in redox-sensory function of PrrB

In order to test the importance of the conserved amino acid residues within the central portion (amino acids 90 to 107) of the PrrB transmembrane domain in the sensory function of PrrB, we performed site-directed mutagenesis on the conserved amino acids. The uncharged amino acids (Leu, Phe, Thr, Pro) were replaced by cysteine or alanine. Cysteine was chosen for future study of cysteine-specific cross-linking experiment. The charged amino acids (Asp, Gln, Asn) were mutated to either a neutral and small amino acid, alanine, or amino acids with the same or opposite charge to investigate the role of the charge of the conserved amino acids in the sensory function of PrrB.

The plasmid pPRRB4[20] carries the $p r r B$ gene cloned into a broad host-range vector pRK415. The pPRRB4 derivatives (pPRRB4D90E, pPRRB4D90N, etc.) have the same construction as pPRRB4 except that the amino acid in the plasmid name has the corresponding point-mutation. The pPRRB4 and its variants were introduced into a prrB-null mutant strain of $R$. sphaeroides (PrrB1) by conjugation and the functionality of PrrB was assessed by complementation tests.

When the PrrB1 mutant strain was mated with E. coli S17-1 strain carrying pPRRB4D90A or pPRRB4N106A, we repeatedly failed to isolate exconjugants on Sistrom's medium A (SIS) plates incubated under aerobic conditions. The exconjugants harboring either pPRRB4N106Q or pPRRB4Q93A appeared to be very unstable under aerobic conditions, i.e., they gave rise to colonies with variegated colorization. For this reason we were unable to further 
PrrB-R.S RegB-R.s RegB-R.d. RegB-R.C.

PrrB-R.s RegB-R.s. RegB-R.d. RegB-R.C.

PriB-R.s. RegB-R.S. RegB-R.d. RegB-R.C.

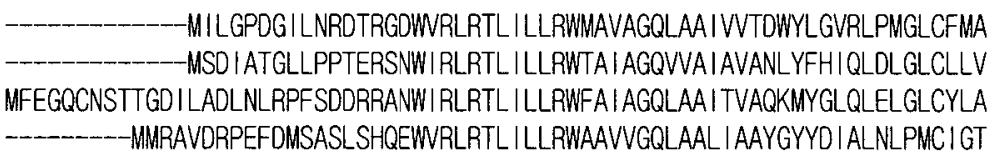

VGASVIANV IATFVFPQNRRLTEFQALMILLFOUTOLSTLIFLTCGITIPFALLILAPVTISALALELRT I GASVLANVI AVAI HPENRRLSEKEAMLTLLFDWDLSALLFLTGELWPFALMLLTPVT I SATALGRMS IGASA IANLVATF IFPENKRLTESQNMLTVLFDI IOLSELLTITGGLUNPFALLMLGPVT I SAAVLTLRS IGFAVAAN IAAIYLYPESRRLSQAEVTATLLFOIMQLALILSLTGGLINPFALL I LVPVT I AATALKLRP

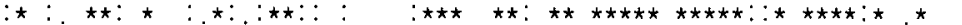

TVILGAIAIGLLTFTAYFHLPLILADGSSLSVPRMFEFGFWLAIVIGILFLGLYSRRRVAIEIRSMSDALL TLFIAHTAFALITMMTFYYVPLVDASGE IQQLPHLFLFGFWAALVIGISFLGLYAORI TSEMNKMSDALL TVFLGGTA I ILVSLLAQFNFPLRTEQGF ILAIPOVFLFGNWIAL I IAIVF ISAYS I RITSE I HSMSDALS TLLLGGAT I AMI TFVAVFNEPLQTRDGAH I GLPPMIEFGSWVAIVIGVIFLGAYAHRIAQE IHSMSDALF

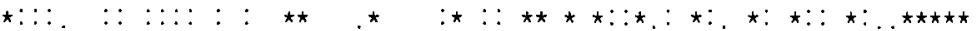

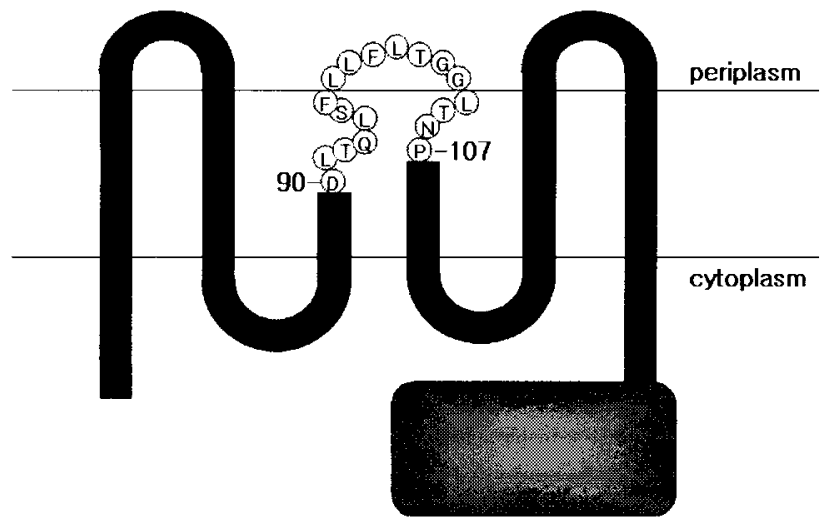

Fig. 1. Multiple alignment of the N-terminal transmembrane domain of PrrB homologues. The highly conserved region in the central part, which was subjected to site-directed mutagenesis, is shaded in gray, and the corresponding part is depicted with amino acid sequence in the schematic model of PrrB. The identical or conservatively substituted residues are indicated by asterisks or colons, respectively. Abbreviations: PrrB-R.s., PrrB from R. sphaeroides; RegB-R.s., RegB from Rhodovulum sulfidophilum; R.d., Roseobacter denitrificans; R.c., Rhodobacter capsulatus.

characterize these mutants in this study. In contrast, exconjugants carrying the other pPRRB4 derivatives were isolated at high efficiency under aerobic conditions following conjugation.

To assess the sensory function of the mutant forms of PrrB, we first examined the effect of the point-mutations on spectral complex formation in the mutants grown under $30 \% \mathrm{O}_{2}$ (aerobic) and anaerobic conditions (Table 1). For the anaerobic growth $R$. sphaeroides strains were grown in the dark in SIS medium supplemented with DMSO as a terminal electron acceptor for anaerobic respiration. The PrrB1 strain with pPRRB4, which synthesizes the wild-type form of PrrB, was used as a positive control strain in the experiment.

As expected, the positive control strain synthesized only basal levels of spectral complexes under aerobic conditions. Under anaerobic conditions where the PrrB1 mutant of $R$. sphaeroides cannot synthesize the spectral complexes, spectral complex formation was induced in the positive control strain, indicating that the prrB gene on pPRRB4 complemented the prrB null mutation in the PrrB1 mutant.

D90N, Q93N, and L94C mutations on PrrB led to strong induction of spectral complex formation under aerobic conditions, which is in keeping with the formation of dark-red colonies of these mutants on SIS plates incubated under aerobic conditions (the positive control strain gave rise to pink colonies on SIS plates under the same growth conditions). The levels of the spectral complexes synthesized in these mutants grown anaerobically were 2.3-2.6 times higher than those in the positive control strain grown under the same conditions.

The intermediate levels of the spectral complexes were formed in the L98C mutant grown under aerobic conditions. The remaining mutants (D90E, Q93E, L97C, 
Table 1. Spectral complex formation in a set of PrrB mutants grown under aerobic and anaerobic conditions

\begin{tabular}{lcccc}
\hline & \multicolumn{4}{c}{ Level of spectral complexes (nmole/mg protein) } \\
\cline { 2 - 5 } \multicolumn{1}{c}{ Strain } & \multicolumn{3}{c}{$30 \% \mathrm{O}_{2}$} & \multicolumn{2}{c}{ Dark DMSO } \\
\cline { 2 - 5 } & $\mathrm{B} 800-\mathrm{B} 850$ & $0.39 \pm 0.04$ & $23.83 \pm 1.33$ & $7.61 \pm 0.41$ \\
\hline PrrB1(pPRRB4) & $0.14 \pm 0.01$ & $0.13 \pm 0.01$ & $13.64 \pm 1.51$ & $7.26 \pm 0.75$ \\
PrrB1(D90E) & $0.07 \pm 0.01$ & $3.02 \pm 0.05$ & $58.83 \pm 0.32$ & $18.40 \pm 0.01$ \\
PrrB1(D90N) & $0.89 \pm 0.00$ & $0.60 \pm 0.03$ & $43.69 \pm 0.81$ & $14.59 \pm 0.07$ \\
PrrB1(Q93E) & $0.22 \pm 0.01$ & $3.17 \pm 0.04$ & $53.89 \pm 1.27$ & $17.32 \pm 0.15$ \\
PrrB1(Q93N) & $0.89 \pm 0.01$ & $2.86 \pm 0.06$ & $62.02 \pm 0.30$ & $20.08 \pm 0.20$ \\
PrrB1(L94C) & $0.87 \pm 0.01$ & $0.23 \pm 0.02$ & $42.10 \pm 0.73$ & $13.74 \pm 0.11$ \\
PrrB1(L97C) & $0.10 \pm 0.01$ & $1.81 \pm 0.04$ & $42.48 \pm 1.26$ & $13.48 \pm 0.33$ \\
PrrB1(L98C) & $0.52 \pm 0.01$ & $0.24 \pm 0.02$ & $48.65 \pm 1.46$ & $14.83 \pm 0.31$ \\
PrrB1(F99C) & $0.10 \pm 0.00$ & $0.37 \pm 0.03$ & $40.97 \pm 0.44$ & $13.30 \pm 0.02$ \\
PrrB1(L100C) & $0.19 \pm 0.00$ & $0.18 \pm 0.01$ & $35.32 \pm 0.38$ & $12.41 \pm 0.06$ \\
PrrB1(T101C) & $0.11 \pm 0.01$ & $0.06 \pm 0.01$ & $47.24 \pm 0.80$ & $14.53 \pm 0.11$ \\
PrrB1(L104C) & $0.08 \pm 0.01$ & $0.12 \pm 0.00$ & $18.21 \pm 0.12$ & $9.49 \pm 0.17$ \\
PrrB1(N106D) & $0.09 \pm 0.00$ & $0.35 \pm 0.04$ & $42.36 \pm 0.94$ & $13.34 \pm 0.11$ \\
PrrB1(P107A) & $0.13 \pm 0.00$ & &
\end{tabular}

For determination of spectral complex levels, strains carrying the corresponding plasmids were grown aerobically by sparging with $30 \% \mathrm{O}_{2}, 69 \% \mathrm{~N}_{2}, 1 \% \mathrm{CO}_{2}$ to an A600 of 0.4 to 0.5 or anaerobically in the dark with DMSO (dark-DMSO). All values are the averages of two independent determinations. B800-850, light harvesting complex II; B875, light harvesting complex I. The names of pPRRB4 derivatives are abbreviated by denoting only the corresponding mutations.

F99C, L100C, T101C, L104C, N106D, and P107A) synthesized basal levels of spectral complexes like the positive control strain, when grown under aerobic conditions. Higher levels of spectral complexes were detected in all the mutants but the D90E and N106D mutants than in the positive control strain when the mutant strains were grown under anaerobic conditions.

On the basis of the results in Table 1, the mutants could be divided into three groups. The first group includes the D90N, Q93N, L94C, and L98C mutants. The mutant forms of $\operatorname{Pr} B$ in this group lost at least in part the sensory function since oxygen-insensitive formation of the spectral complexes occurred in the mutants of this group. The equilibrium of kinase/phosphatase activities of $\operatorname{Pr} B$ in this group is in the kinase-dominant mode regardless of presence or absence of oxygen. The Q93A and N106Q might also belong to this group. It can be assumed that the Q93A and N106Q mutants are unstable under aerobic conditions because PS gene expression might be very highly induced in these mutants even under aerobic conditions, which is toxic to the cell in the presence of $\mathrm{O}_{2}[20]$.

The D90E and N106D mutants comprise the second group. Spectral complex formation in the D90E and N106D mutants was inhibited under aerobic conditions and induced under anaerobic conditions as observed for the positive control strain. However, significantly less amounts of the spectral complexes were synthesized in these mutants grown anaerobically than in the control strain grown under the same conditions, indicating that the equilibrium of kinase/phosphatase activities of the D90E and N106D mutant forms of PrrB inclines to the phosphatase mode relative to that of the wild-type PrrB.

The last group is composed of the Q93E, L97C, F99C, L100C, T101C, L104C, and P107A mutants. The regulation pattern of spectral complex formation in the mutants of this group in response to changes in oxygen tensions was similar to that observed for the positive control strain although higher anaerobic induction of spectral complex formation was observed in the mutants than in the control strain. This fact implies that the mutant forms of $\operatorname{Pr} B$ of the last group retain the redox-sensory function.

Taken together, the results presented in Table 1 suggest that Asp-90, Gln-93, Leu-94, Leu-98, and Asn-106 among the amino acids, which are located in the $3^{\text {rd }}$ and $4^{\text {th }}$ transmembrane helices and the $2^{\text {nd }}$ periplasmic loop of PrrB, play an important role in the sensory function of PrrB. Interestingly, when Asp-90 was changed to Asn with the opposite charge, the sensory function of $\operatorname{Pr} B$ was severely compromised as judged by strong aerobic induction of spectral complex formation. In contrast, when Asp-90 was mutated to Glu with the same charge as Asp, the mutant form of PrrB retained its sensory function in spite of some 
defects in anaerobic induction of spectral complex formation, implying that the charge on Asp-90 is important for the PrrB sensory function.

The Q93N and Q93A forms of PrrB are defective in PrrB sensory function, whereas the Q93E mutant form of PrB is normal with regard to the sensory function, implying that the size of the side chain of Gln-93 rather than its charge is important for the PrrB sensory function.

In the case of Asn-106, the N106Q mutation led to instability of the mutant under aerobic conditions, which is reflective of very strong induction of PS gene expression under aerobic conditions. The N106D mutant form of PrrB still retained the sensory function. Both results imply that the size of the side chain of Asn-106 is important for the sensory function of PrrB.

The puf operon encodes the apoproteins of the light harvesting complex I (B875) and reaction center and its expression is the under the control of the PrBA two-component system $[1,4]$. The expression of the puf operon was examined at the transcriptional level by means of Northern hybridization analyses using total RNA isolated from the $\begin{array}{lllll}\text { mutant and control strains grown under } & 30 \% & \mathrm{O}_{2}\end{array}$ conditions. As shown in Fig. 2, the expression of the puf operon was significantly derepressed in the D90N, Q93N, L94C, and L98C mutant strains, which is in good agreement with the formation of the spectral complexes in these mutants grown aerobically (see Table 1). This result confirms that the D90N, Q93N, L94C, and L98C mutant forms of PrrB are defective in their sensory function.

There are two theories that explain the mechanism by

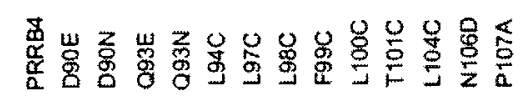

$30 \% \mathrm{Oz}$
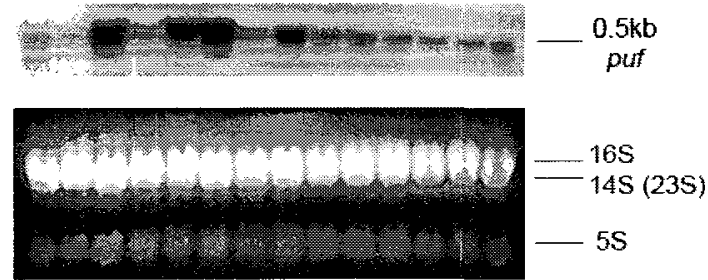

Fig. 2. Analysis of puf mRNA in $R$. sphaeroides strains grown aerobically by sparging with $30 \% \mathrm{O}_{2}, 69 \% \mathrm{~N}_{2}, 1 \% \mathrm{CO}_{2}$ to $\mathrm{A}_{600}$ of 0.4 to 0.5 . Approximately $20 \mu \mathrm{g}$ of total RNA was loaded in each lane. The Northern blots were probed with a labeled $0.47-\mathrm{kb}$ StyI fragment from pUI655 which is specific for puf mRNA. The same levels of processed 235 rRNA (14S), 16S, and 5S rRNA in each lane indicate that the same amounts of total RNA were used in Northern blot analysis. which PrrB perceives oxygen tension in the environment. According to the first theory, the PrrB histidine kinase does not sense the oxygen tension by itself. Instead, the $c b b_{3}$ cytochrome $c$ oxidase in the respiratory electron transport system of $R$. sphaeroides functions as a redox sensor $[15,17,18,20,21]$. In the presence of $\mathrm{O}_{2}$ the $c b b_{3}$ oxidase generates an inhibitory signal to $\operatorname{Pr} B$, which shifts the equilibrium of PrrB kinase/phosphatase activities toward the phosphatase dominant mode by increasing the phosphatase activity without alterations of PrrB kinase activity. In the absence of $\mathrm{O}_{2}$ the inhibitory signal emanating from the $c b b_{3}$ oxidase diminishes and the activity of $\operatorname{Pr} B$ is thereby in the default state, i.e., the kinase-dominant mode[20]. The nature of the ihhibitory signal remains to be elucidated. However, it was clearly demonstrated in vitro that the purified $c b b_{3}$ oxidase alone increased the PrrB phosphatase activity without changes in the kinase activity[21], implying that the nature of the signal might be the conformational change of the $c b b_{3}$ oxidase induced in response to changes in oxygen tension and that the signal might be transferred from the $c b b_{3}$ oxidase to PrrB by direct protein-protein interactions. If this were true, the amino acids identified in this study might be involved in protein-protein interactions between PrrB and $c b b_{3}$ cytochrome $c$ oxidase.

The other theory says that the PrrB histidine kinase directly senses the oxygen tension in the environment by monitoring the redox state of the ubiquinone/ubiquinol pool in the electron transport system[24]. Recently it was reported that the second periplasmic loop of the $\operatorname{Pr} B$ transmembrane domain serves as a binding site of ubiquinone and the binding of ubiquinone to PrrB was shown to reduce the autophosphorylation rate of $\operatorname{PrrB}[24]$. If this were the case, the amino acids identified in this study might play a crucial role in forming the binding motif of quinone.

\section{Purification of the wild-type and mutant forms (D90E, D90N, D90A) of PrrB}

We first chose the D90E, D90N, and D90A mutant forms of PrrB for further in vitro study. To purify the PrrB protein by affinity chromatography, the $\operatorname{pr} B$ gene was modified by adding 9 consecutive histidine codons immediately before its stop codon and the modified gene was cloned into an expression vector PT7-7. The resulting expression plasmid was subjected to site-directed mutagenesis to construct 


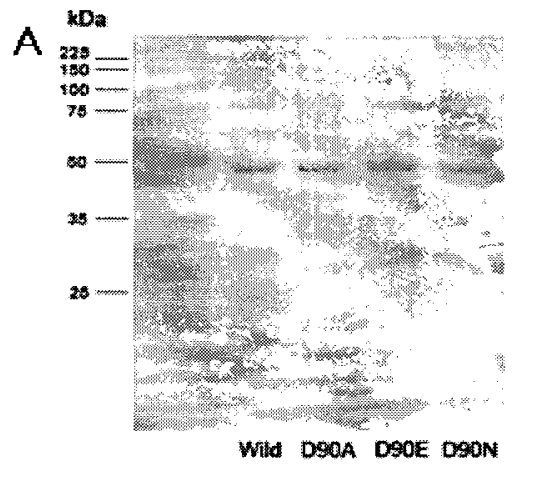

B

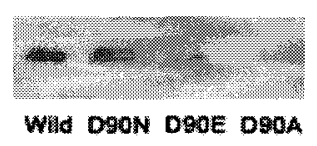

Fig. 3. Purification of wild-type form (wild) and mutant forms (D90A, D90E, and D90N) of PrrB (A) and in vitro autophosphorylation assay (B). The purified proteins were resolved by SDS-PAGE (12.5\% polyacrylamide gel) and visualized by staining with Coomassie brilliant blue. $2.5 \mu \mathrm{g}$ of purified proteins were loaded in each lane. Autophosphorylation assay was performed using $1 \mathrm{\mu g}$ of purified proteins as described in materials and methods.

the expression plasmids for the mutated PrrB (D90E, $\mathrm{D} 90 \mathrm{~N}$, and D90A forms). When the prrB gene was overexpressed in the E. coli Bl21 strain, the gene product was detected in the membrane fraction. Using the detergent, $n$-dodecyl $\beta$-D-maltoside, PrB and its mutant derivatives were solubilized and successfully purified to over $90 \%$ homogeneity by a single-step chromatography (Fig. 3A). The apparent molecular mass of PrrB was estimated to be approximately $45 \mathrm{kDa}$ as judged by SDS-PAGE, which is consistent with the value reported previously[21]. We first examined the functionality of purified PrrB by probing the ability of PrrB to autophosphorylate using ATP. When $1 \mu$ $\mathrm{g}$ (19.1 pmol) of purified PrrB was incubated with $[\gamma$ $\left.{ }^{32} \mathrm{P}\right] \mathrm{ATP}$ for $3 \mathrm{~min}$ at room temperature, the wild-type and mutant forms (D90N and D90E) of PrrB were autophosphorylated (Fig. 3B) while The D90A form of PrrB was not phosphorylated. The extent of autophosphorylation of the D90N PrrB was shown to be greater than that of the wild-type form of PrrB. The autophosphorylation rate of the D90E PrrB was lower than that of the wild-type form of PrrB. These results are in agreement with the in vivo phenotype of the mutant strains, i.e., increase and decrease in spectral complex formation in the D90N and D90E mutant strains, respectively, as compared to the positive con- trol strain.

In this study we examined only the autokinase activities of mutant forms of PrrB. It is necessary to investigate the kinase/phosphatase activities of the mutant forms of $\operatorname{Prr} B$ using the purified PrrA and we are now in process of such studies.

\section{Acknowledgement}

This work was supported by Korea Research Foundation Grant (KRF-2004-015-C00488) to Jeong-Il Oh.

\section{References}

1. Choudhary, M., and S. Kaplan. 2000. DNA sequence analysis of the photosynthesis region of Rhodobacter sphaeroides 2.4.1. Nucleic Acids Res. 28, 862-867.

2. Comolli, J.C., A. J. Carl, C. Hall, and T. Donohue. 2002. Transcriptional activation of the Rhodobacter sphaeroides cytochrome $\mathrm{c}_{2}$ gene $\mathrm{P} 2$ promoter by the response regulator PrrA. J. Bacteriol. 184, 390-399.

3. Davis, J., T. J. Donohue, and S. Kaplan. 1988. Construction, characterization, and complementation of a Puf- mutant of Rhodobacter sphaeroides. J. Bacteriol. 170, 320-329.

4. Eraso, J. M., and S. Kaplan. 1994. prrA, a putative response regulator involved in oxygen regulation of photosynthesis gene expression in Rhodobacter sphaeroides. J. Bacteriol. 176, 32-43.

5. Eraso, J. M., and S. Kaplan. 1995. Oxygen-insensitive synthesis of the photosynthetic membranes of Rhodobacter sphaeroides: a mutant histidine kinase. J. Bacteriol. 177, 2695-2706.

6. Eraso, J. M., and S. Kaplan. 1996. Complex regulatory activities associated with the histidine kinase $\operatorname{Pr} B$ in expression of photosynthesis genes in Rhodobacter sphaeroides 2.4.1. J. Bacteriol. 178, 7037-7046.

7. Gomelsky, M., and S. Kaplan. 1995. appA, a novel gene encoding a trans-acting factor involved in the regulation of photosynthesis gene expression in Rhodobacter sphaeroides 2.4.1. J. Bacteriol. 177, 4609-4618.

8. Gomelsky, M., and S. Kaplan. 1995. Genetic evidence that PpsR from Rhodobacter sphaeroides 2.4.1 functions as a repressor of puc and bchF expression. J. Bacteriol. 177, 1634-1637.

9. Kaplan, S., J. M. Eraso, and J. H. Roh. 2005. Interacting regulatory networks in the facultative photosynthetic bacterium, Rhodobacter sphaeroides 2.4.1. Biochem. Soc. Trans. 33, 51-55.

10. Keen, N. T., S. Tamaki, D. Kobayashi, and D. Trollinger. 1988. Improved broad-host-range plasmids for DNA cloning in gram-negative bacteria. Gene 70, 191-197.

11. Kiley, P. J., and S. Kaplan. 1988. Molecular genetics of 
photosynthetic membrane biosynthesis in Rhodobacter sphaeroides. Microbiol. Rev. 52, 50-69.

12. Kobe, B., and J. Deisenhofer. 1994. The leucine-rich repeat: a versatile binding motif. Trends Biochem. Sci. 19, 415-421.

13. O'Gara, J.P., J. M. Eraso, and S. Kaplan. 1998. A redox-responsive pathway for aerobic regulation of photosynthesis gene expression in Rhodobacter sphaeroides 2.4.1. I Bacteriol. 180, 4044-4050.

14. O'Gara, J. P., and S. Kaplan. 1997. Evidence for the role of redox carriers in photosynthesis gene expression and carotenoid biosynthesis in Rhodobacter sphaeroides 2.4.1. J. Bacteriol. 179, 1951-1961.

15. Oelmuller, U., N. Kruger, A. Steinbuchel, and C. .G. Friedrich. 1990. Isolation of procaryotic RNA and detection of specific mRNA with biotinylated probes. J. Microbiol. Methods 11, 73-84.

16. Oh, J. I., J. M. Eraso, and S. Kaplan. 2000. Interacting regulatory circuits involved in orderly control of photosynthesis gene expression in Rhodobacter sphaeroides 2.4.1. J. Bacteriol. 182, 3081-3087.

17. Oh, J. I., and S. Kaplan. 1999. The $\mathrm{cbb}_{3}$ terminal oxidase of Rhodobacter sphaeroides 2.4.1: structural and functional implications for the regulation of spectral complex formation. Biochemistry 38, 2688-2696.

18. Oh, J. I., and S. Kaplan. 2000. Redox signaling: globalization of gene expression. EMBO J. 19, 4237-4247.

19. Oh, J. I., and S. Kaplan. 2001. Generalized approach to the regulation and integration of gene expression. Mol. Microbiol. 39, 1116 - 1123.

20. Oh, J. I., I. J. Ko, and S. Kaplan. 2001. The default state of the membrane-localized histidine kinase PrrB of Rhodobacter sphaeroides 2.4 .1 is in the kinase-positive mode. J. Bacteriol. 183, 6807-6814.

21. Oh, J. I., I. J. Ko, and S. Kaplan. 2004. Reconstitution of the Rhodobacter sphaeroides $\mathrm{cbb}_{3}$-PrrBA signal transduction pathway in vitro. Biochemistry 43, 7915-7923.

22. Ouchane, S., and S. Kaplan, 1999. Topological analysis of the membrane-localized redox-responsive sensor kinase PrrB from Rhodobacter sphaeroides 2.4.1. J. Biol. Chem. 274, 17290-17296.

23. Sambrook, J., E. F. Fritsch, and T. Maniatis. 1989. Molecular Cloning: a Laboratory Manual. Cold Spring Harbor Laboratory, Cold Spring Harbor, NY.

24. Swem, L. R., X. Gong, C. A. Yu, and C. E. Bauer. 2006. Identification of a ubiquinone binding site that affects autophosphorylation of the sensor kinase RegB. J. Biol. Chem. 281, 6768-6775.

25. Zeilstra-Ryalls, J. H., and S. Kaplan. 1996. Control of hemA expression in Rhodobacter sphaeroides 2.4.1: regulation through alterations in the cellular redox state. J. Bacteriol. 178, 985-993.

26. Zeilstra-Ryalls, J. H., and S. Kaplan. 1998. Role of the fnrL gene in photosystem gene expression and photosynthetic growth of Rhodobacter sphaeroides 2.4.1. J. Bacteriol. 180, 1496-1503.

\title{
초록 : Site-directed mutagenesis에 의한 PrrB histidine kinase의 신호인지 기능에 관련된 아미노산의 발굴
}

\author{
김용진 · 고인정 ${ }^{1}$ · 오정일* \\ (부산대학교 자연과학대학 미생물학과, ${ }^{1}$ 한국과학영재학교)
}

광합성세균인 Rhodobacter sphaeroides의 PrrBA two-component system은 산소분압의 변화에 따라 광합성 유전 자의 발현을 조절하는 주요한 조절계 중 하나이다. PrrBA two-component system은 PrrB histidine kinase와 $\operatorname{PrrA}$ response regulator로 구성되어 있는데, PrrB의 $\mathrm{N}$-말단 transmembrane 도메인은 신호인지 도메인으로서, 여섯 개의 transmembrane helix가 세 개의 periplasmic loop와 두 개의 cytoplasmic loop을 형성하고 있다. 그 중 세 번째, 네 번째 transmembrane helix와 두 번째 periplasmic loop가 산화/환원 인지 기능에 있어 중요한 역할을 할 것이라고 제안되었다. 본 연구에서는, 두 번째 periplasmic loop와 그 인접 부위에서의 돌연변이 (Asp-90, Gln-93, Leu-94, Leu-98, Asn-106)에 의해 PrrB의 인지 기능에 있어 심각한 결함이 생기는 것을 증명하였 고, 이는 이 아미노산들이 PrrB의 산화/환원 인지 기능에 연관되어 있을 수 있다는 것을 보여준다. PrrB의 돌연변 이 형태 (D90E, D90N, D90A)가 대장균에서 과발현되어서 affinity chromatography에 의해 정제되었고, 정제된 단백질의 자가인산화 반응이 측정되었다. PrrB D90N 변이형태는 PrrB wild-type보다 높은 자가인산화 활성을 가지는 반면에, $\operatorname{PrrB} \mathrm{D} 90 \mathrm{E}$ 변이형태는 $\operatorname{PrrB}$ wild-type보다 낮은 자가인산화 활성을 나타내었다. 그리고 D90A 변이형태는 $\mathrm{PrBB}$ 의 자가인산화 활성이 매우 약화되었다. 